\title{
Freshwater protected areas: an effective measure to reconcile conservation and exploitation of the threatened European eels (Anguilla anguilla)?
}

\author{
Julien Cucherousset ${ }^{1,{ }^{*}}$, Jean-Marc Paillisson ${ }^{1}$, Alexandre Carpentier $^{1}$, Vincent \\ Thoby $^{2}$, Jean-Patrice Damien ${ }^{2}$, Marie-Christine Eybert ${ }^{1}$, Eric Feunteun and Tony \\ Robinet $^{4}$
}

\author{
${ }^{1}$ Equipe Biologie des Populations et de la Conservation, UMR 6553 ECOBIO CNRS, Université of Rennes 1, \\ Rennes, France. \\ ${ }^{2}$ Parc naturel régional de Brière, Saint Joachim, France. \\ ${ }^{3}$ Muséum national d'histoire naturelle, Station marine de Dinard, France. \\ ${ }^{4}$ Centre de Recherche sur les Ecosystèmes Littoraux Anthropisés (CRELA), UMR6217 CNRS-IFREMER- \\ Université de La Rochelle, La Rochelle, France
}

\begin{abstract}
*: Corresponding author : Julien Cucherousset, EcoLab - Laboratoire d'écologie fonctionnelle, UMR 5245 (CNRS-UPS-INPT), Université Paul Sabatier, bât 4R3, 118, route de Narbonne, 31062 Toulouse Cedex 9, France; e-mail: julien.cucherousset@cict.fr
\end{abstract}

Keywords: Anguilla-anguilla; spawners-production; protected-area; habitat-restoration; coastalfreshwater-marsh

\begin{abstract}
:
For decades, the European eel Anguilla anguilla (L.) population has been declining strongly despite several management attempts, so additional experiments need to be conducted on management measures. The use of freshwater protected areas has been advocated but their efficiency has never been assessed. In this study, we investigated whether the population structure and the silver eel (mature migrating stage) production differ in fished and protected areas within a marsh wetland (Brière, 7000 ha, Northwest France), using an intensive biological study (electrofishing and trapping) and a survey of the traditional fishery (licenses, questionnaires and creel surveys). First, we found that fishermen mainly targeted $>320-\mathrm{mm}$ yellow eels (sedentary stage) using pots and square dipping nets and that harvest by fishermen was highly variable at different locations in the study area. Secondly, we found differences in the size-class structures and mortality rates between protected and fished areas. Mortality rates of eels $>320 \mathrm{~mm}$ was positively correlated with harvest by fishermen. Furthermore, the proportion of potentially migrating eels in the total population was found to be higher in the protected areas than in fished areas $(6.38 \%$ vs. $1.42 \%$, respectively). Thirdly, we found that protected areas potentially produce $8.4 \%$ of the total silver eel production whereas they only account for $2.4 \%$ of the aquatic habitat area. We estimated that a size adjustment of protected areas to 31.1\% with maintaining the current fishery would produce $50 \%$ of the potential silver eel of a fully protected marsh. Protection of freshwater areas appears to be a promising management measure and a constructive consensual way to integrate the patrimonial and societal value of the traditional fishery and the international management plans for European eels. Furthermore, freshwater protective measures can be an effective local solution if they are integrated into the framework of freshwater biodiversity
\end{abstract}


54 management and accompanied by other management measures that focus on all eel life 55 stages.

\section{Introduction}

The European eel Anguilla anguilla (L.) population is in a steep decline that

59 began in the 1970s (Moriarty \& Dekker 1997; Feunteun 2002; ICES WGEEL 2006). The

60 most frequently cited causes of decline are: global warming and its effects on marine

61 currents and ocean productivity, obstructions to migration, fisheries, habitat degradation

62 and parasite infestations (Feunteun 2002; Robinet \& Feunteun 2002; Starkie 2003).

63 Attempts to manage and restore local stocks include (see review in Feunteun 2002) (i)

64 regulation of fisheries at various biological stages (e.g. Rosell et al. 2005), (ii)

65 management of obstacles to migration in particular fish passes (e.g. Knights \& White 66 1998), and (iii) restocking programs (e.g. Moriarty \& Dekker 1997). Despite all these 67 programs, the general decline continues and additional management measures need to be 68 developed. Since 1999, the ICES Working Group on Eel has recommended reducing 69 anthropogenic impacts on production and escapement of silver eels (i.e., mature 70 migrating stage) to the lowest possible levels (ICES WGEEL 2006). Now, the situation is 71 becoming increasingly critical for the eel fisheries, and ICES experts expressly demand 72 to identify "areas producing high quality silver eels (large sized females, low contaminant 73 and parasite burdens, unimpacted by hydropower stations)", in order to prioritize their

74 conservation (ICES WGEEL 2006). Concrete actions must now be focused on the 75 quantity and quality of the future silver eels leaving freshwaters (Dekker 2003). 
Marine protected areas have been proposed as an easily enforced conservation

77 method for managers to reduce the impacts of fishing on marine populations and habitats

78 (Apostolaki et al. 2002). Scientists have developed practical and theoretical approaches

79 for the design and the implementation of marine protected areas that have benefits for

80 biodiversity and fisheries threatened by anthropogenic activities (see review in Leslie

81 2005). Recent research has shown that the success of marine protected areas also depends

82 on the integration of social, economic, political and scientific factors (Lundquist \&

83 Granek 2005; Stem et al. 2005). Some attempts have been recently conducted worldwide,

84 with variable success, to develop freshwater protected areas (Maitland 1995; Keith 2000;

85 Saunders et al. 2002). Few areas have been created specifically for freshwater fish, and

86 almost all freshwater protected areas were included "incidentally" as part of terrestrial

87 reserves (Eybert et al. 1998; Keith 2000; Self 2005). Although freshwater protected areas

88 have been advocated for management of American and European eel stocks (Feunteun

89 2002; Morrison \& Secor 2003), their utility for conservation has not been evaluated.

90 Small freshwater coastal marshes are useful for studying this issue in France

91 because they are widely colonized by eels (Feunteun et al. 1992) and in recent decades,

92 habitat restoration programs have been undertaken and in some cases freshwater

93 protected areas were created. These ecosystems also comprise recreational and traditional

94 eel fisheries and their limited size allows the whole local eel population to be studied.

95 Furthermore, the role played by many small inland ecosystems in terms of silver eel

96 production remains to be quantified (Feunteun et al. 2000). The configuration of the

97 Grande Brière Mottière (GBM, western France) offers good opportunities to test the

98 efficiency of protected areas for eels because this coastal freshwater marsh has a

99 traditional fishery and two protected areas that were created in the early 1980s. 
101 traditional fishery survey, the objectives of the present study are (1) to characterize the

102 yellow eel (i.e., sedentary stage) size-classes targeted by the local fishery and the spatial

103 distribution of catches, (2) to compare the eel population structure between fished and

104 protected areas by analyzing size-class distributions, mortality rates and silver eel

105 production, (3) to measure how the fisheries impact the eel size-class structure, and

106 finally (4) to estimate the local eel stock and the differences in silver eel production in

107 order to evaluate the efficiency of protected areas on the quantity and quality of the future

108 silver eels leaving the GBM.

110 Materials and methods

111 Study area

112 The Grande Brière Mottière is a freshwater and coastal wetland marsh of 7000 ha 113 that flows in the Loire River estuary (North West France, $47^{\circ} 22^{\prime} \mathrm{N}, 02^{\circ} 11^{\prime} \mathrm{W}$ ). The 114 aquatic habitat is composed of a complex network of permanent ditches $(144 \mathrm{~km}$ 115 representing $206.4 \mathrm{ha}$ ) and semi-permanent ponds (392.7 ha) within a patchwork of 116 temporary flooded wetlands composed of grasslands and reed beds (Figure 1). In the 117 general framework of restoration programs developed in the early 1980s to limit the 118 expansion of reed beds (Bernard \& Rolland 1990), two protected areas where fishing, 119 hunting and entry are totally prohibited have been created (Eybert et al. 1998, Figure 1).

120 The southern and northern protected areas were created in 1973 and 1989, and cover 700

121 ha and 250 ha of land composed of 8.1 and 6.5 ha of aquatic habitat, respectively. Based 
122 on traditional habits, the study site is divided into eight zones where fishing is permitted 123 plus the two protected areas (Figure 1).

125 Traditional fishery survey

126 Data from the traditional fishery survey were used to estimate the targeted eels 127 sizes, the fishing effort and the fishery harvest from questionnaires. Since 1784, the 128 Grande Brière Mottière marsh had its own property law (“undivided” and privately 129 owned) and a specific fishery legislation, the fishery being composed of non-commercial 130 fishermen. In this marsh, no minimum legal size regulation exists. In 2005, a fishery 131 survey was conducted to assess the harvest by fishermen (expressed as the number of eels 132 captured per ha) for each type of gear at different zones of the study area (Figure 1) using 133 three different methods. Firstly, all fishing licences were analysed to count the number of 134 fishermen and to assess the total number of gear used (product of the number of 135 fishermen with the mean ( \pm SE) number of each gear per fishermen). Secondly, 136 anonymous questionnaires were distributed to evaluate the fishing practices since 137 logbooks were rarely available. During the fishing season, questionnaires were randomly 138 distributed directly to fishermen in the field or via fishermen associations. Follow-up 139 contacts were to improve the response rate. Fishermen were questioned on the species 140 targeted, their catches, the number and type of gear and the frequency and location of 141 their trips. The representativeness of the questioned fishermen was checked to ascertain 142 the wider application of the data (Roth et al. 2001) by comparing these fishermen to the 143 total fishing licences using a $\chi^{2}$ test. Thirdly, some fishermen were accompanied during 144 their trips (creel survey) to assess the size-classes targeted by comparing the total 145 captures with those fish released. Based on the fishermen logbooks available $(n=3)$, we 
146 found that eel captures occurred mainly in May (73\% of total captures) as a result of a 147 very limited seasonal efficiency of fishing gears with respect to the local water regime.

148 Based on questionnaires, we calculated the number of eels caught during this month by 149 multiplying the number of fishermen with the mean ( \pm SE) number of each gear per 150 fishermen and with the mean $( \pm$ SE) catch per unit effort for of each gear and then the 151 total number of catches was extrapolated from the survey results for the whole year.

Eel population survey

Sampling

The eel population was sampled in 2004 and 2005 using trapping and 156 electrofishing (Figure 1 and Table 1). Trapping at randomly chosen locations was used to 157 assess population parameters (i.e., size-class profiles, proportion of silver eels and sex 158 ratio) in restricted locations of the protected and fished areas. It was conducted using fyke 159 nets (two wings $1.2 \mathrm{~m}$ high and $3 \mathrm{~m}$ long directing the fish into the $2 \mathrm{~m}$ long and $50 \mathrm{~cm}$ 160 diameter chamber of $5 \mathrm{~mm}$ mesh) and fishermen eel pots (1.5 m long with 1.0 x $0.4 \mathrm{~m}$ 161 frames and $10 \mathrm{~mm}$ mesh). All trapping data (fishermen creel and scientific surveys) 162 were pooled to increase the number of eels sampled (Table 1). Because trapping was not 163 applicable to the whole study area, electrofishing was randomly conducted at different 164 locations over the whole study area in 2004 and 2005 to assess the geographical variation 165 in eel abundance (Figure 1 and Table 1). Sampling was conducted with an EFKO F.E.G. 1668000 apparatus using the point abundance sampling method (PAS, Nelva et al. 1979), 167 with the PAS number per site being in accordance with Copp \& Garner's (1995) 168 recommendations. Indeed, PAS is an efficient and cost-effective method for assessing 
169 fish abundance and population structure and provides reproducible and quantitative 170 samples that allows within- and between-sites comparisons (Copp 1989). In total, we 171 conducted 1225 PAS in 17 and 30 sites sampled in 2004 and 2005, respectively (details

172 in Table 1). Abundance was expressed in Catch per Unit Effort (CPUE), i.e. the number 173 of eels caught per PAS.

174 For the two sampling methods, eels were anesthetized with eugenol $\left(0.04 \mathrm{~mL} \cdot \mathrm{L}^{-1}\right)$, 175 measured (total length TL to the nearest $\mathrm{mm}$ ), weighed ( $\mathrm{W}$, to the nearest $\mathrm{g}$ ), 176 macroscopic silvering criteria were assessed (Acou et al. 2005), and then the eels were 177 released into the water. Given that some differences might occur in the selectivity of 178 trapping gear in relation to different mesh sizes, only eels longer than the modal body 179 size (i.e., TL $=320 \mathrm{~mm}$ ) were used for further analyses (Naismith \& Knights 1990; 180 Knights et al. 1996). Given that elvers (post larval stage stage, $<150 \mathrm{~mm}, \mathrm{n}=32$ ) have 181 only colonized the drainage during the current year and have a higher downstream 182 abundance, they were removed from the data set obtained by electrofishing to avoid any 183 biases in the analyses. Where nonparametric tests showed no difference, data collected in 1842004 and 2005 were combined with respect to the sampling method (trapping and 185 electrofishing).

\section{Population parameters}

188 The total mortality rate per year $(\mathrm{Z})$ was calculated in the protected and fished 189 areas using the age-size relationship established in a nearby and very similar ecosystem 190 (at $60 \mathrm{~km}$ distance in Grand-Lieu lake; Adam 1997). Assuming that $\mathrm{Z}$ remains constant 191 throughout the life of the cohort and that the population is in a state of equilibrium, $\mathrm{Z}$ was 192 calculated for fish under full exploitation, i.e. individuals submitted to the fishery from 
193 age-5 to age-7 without seaward emigration, using the following formula (see Sparre \&

194 Venema (1998) for details):

$195 \quad N_{(\text {age }=7)}=N_{(\text {age }=5)} \times e^{(-Z \times t)}$

196 where $\mathrm{N}_{(\mathrm{age}=5)}$ is the number of individuals of age 5 entering the fully exploited phase,

$197 \mathrm{~N}_{(\mathrm{age}=7)}$ is the number of individuals of age 7 (end of the fully exploited phase), $t$ is the

198 time in year and $\mathrm{Z}$ the total mortality rate expressed in percentage of individual per year.

199 The mortality rate calculation was performed at the study area scale (i.e., protected vs.

200 fished areas), and not for each zone given the insufficient number of individuals sampled

201 in each zone. At the zone scale, mortality was estimated by calculating the difference in

202 abundance obtained by electrofishing (expressed in CPUE) between untargeted and 203 targeted eel size-classes.

204 In 2005, the proportion of silver eels was determined using a standardized method 205 based on macroscopic criteria (ocular index, state of differentiation of the lateral line and 206 colour contrast) that provides a quick identification in the field of pre-migrant eels in a 207 standardized way and without sacrificing any individuals (Acou et al. 2005). However, 208 this method was applied to data collected later in the season (i.e., September and October, 209 Acou et al. 2005), so we used two earlier criteria of silvering prior to this (i.e. ocular 210 hypertrophy and differentiation of the lateral line). Indeed, the typical pigmentation of 211 silver eel occurred generally at the end of the silvering process (Acou et al. 2005; Durif et 212 al. 2005). Because few silver eels were sampled in protected area by electrofishing, the 213 proportion of silver eels in the protected areas was calculated using the proportion of 214 silver eels in fished area multiplied by the silvering ratio between protected and fished 215 areas. In addition, we used the Fulton's condition factor $\left(K=W \times T L^{-3} \times 100000\right)$ as a 
216 general indicator of pre-migrant quality (EELREP, 2005), and used the $440 \mathrm{~mm}$ threshold

217 to assess the sex of silver eels since no individuals were sacrificed during the study.

218 Individuals longer than $440 \mathrm{~mm}$ are known to be females (Tesch 2003; Acou et al. in

219 press). The sex ratio was expressed as the proportion of males among pre-migrant eels.

The assessment of eel stocks in extensive areas is particularly difficult. Indeed, the

223 most common technique (depletion sampling associated with electrofishing) consumes

224 manpower and time and thus is not easily applicable in extensive areas (Lobon-Cervia \&

225 Utrilla 1993). Nevertheless, a method has been developed to point sample the eel

226 abundance in freshwater areas by establishing the relationship between PAS and

227 depletion samples (Laffaille et al. 2005a). These authors recommended developing a

228 single relationship for each type of equipment and habitat (Laffaille et al. 2005b).

229 Furthermore, the authors found that this relationship is linear at variable eel densities

230 (expressed as number of eel $\cdot 100 \mathrm{~m}^{-2}$, Laffaille et al. 2005a). Using the habitat

231 differentiation between the shoreline and open water (Broad et al. 2001; Schulze et al.

232 2004), we established the following relationship in a typical ditch of the Brière marsh

233 based on 25 PAS distributed in two sites sampled by depletion:

Eel density (in eel $\left.\cdot 100 \mathrm{~m}^{-2}\right)=10.59( \pm 1.55$ S.E.) Eel relative abundance (in CPUE from PAS).

No differences in the size-class distribution of eels between PAS and depletion 237 sampling were found (Kolmogorov-Smirnov two-sample test, $\mathrm{KS}=0.201, \mathrm{P}>0.602, \mathrm{n}=$ 238 57). Eel stock assessment was derived from this relationship and the estimation of the 
239 area of each type of habitat (shoreline and open water) using a Geographical Information 240 System (source Parc naturel regional de Brière).

241 Next, we used the mortality rates estimated in protected and fished areas and the 242 estimated eel stock under exploitation (eels $>320 \mathrm{~mm}$, see results section) to evaluate the 243 fishing mortality based on scientific data. We used the formula:

$244 \quad Z=F+M$

245 where $\mathrm{Z}$ is the total mortality, $\mathrm{F}$ is the fishing mortality and $\mathrm{M}$ is the natural mortality and 246 making the assumption that recruitment and population parameters were similar in 2004 247 and 2005 (see section on population parameters). Thus, in the protected areas, the fishing 248 mortality was assumed to be zero $(\mathrm{F}=0)$ and thus resulting in $\mathrm{M}=\mathrm{Z}$. For the calculation 249 of $\mathrm{F}$ at the fished areas, the $\mathrm{M}$ value was subtracted from the $\mathrm{Z}$ value in order to obtain 250 the fishing mortality $(\mathrm{F}=\mathrm{Z}-\mathrm{M})$. The number of eels caught by the fishery $\left(\mathrm{N}_{\mathrm{F}}\right)$ was 251 estimated using the following formula and equations (1) and (2):

$252 \quad N_{F}=N_{(a g e=5)} \times\left(1-e^{(-t \times(F+M))}\right) \times(F /(F+M))$

253 where $\mathrm{N}_{\mathrm{F}}$ is the number of eels that died from fishing mortality, $\mathrm{N}_{(\mathrm{age}=5)}$ is the number of 254 individuals of age 5 entering the fully exploited phase and $t$ is the average number of 255 years an eel is experiencing exploitation (i.e., 3 years). Next, estimated $\mathrm{N}_{\mathrm{F}}$ was compared 256 qualitatively to the results obtained from fishermen questionnaires. Finally, silver eel 257 production was derived from the estimated eel stock and the proportion of silver eels in 258 both protected and fished areas. All estimates (number and biomass of eels) and their 259 upper and lower values (in parentheses) resulted from the products of the lower values 260 (mean - SE), the means and the upper values (mean + SE) of the population parameters. 


\section{Results}

263 The traditional fishery

264 A total of 521 fishing licences were sold in the Grande Brière Mottière marsh in 265 2005: 34 for the use of eel pots, 66 for square dipping nets and 46 for fish spears; the rest 266 of the licences being attributed for gill nets, rods and multiple gears. Nevertheless, 267 gillnets and rods are principally used to catch piscivorous fish (northern pike Esox lucius 268 and pikeperch Sander lucioperca). The eel fishery was composed of 48 fishermen using 269 pots, 87 using square dipping nets and 60 using spears. In total, 75 fishermen responded 270 to the questionnaires and provided data, including 28 using pots, 43 using square dipping 271 nets and 26 using spears, i.e., approximately one-half of the total number of fishermen for 272 each gear. Furthermore, the set of fishermen that responded to the questionnaires did not 273 differ significantly from the whole eel fishery (Chi-square, d.f. $=2, \chi^{2}=0.797, \mathrm{P}<0.671$ ). 274 Based on these questionnaires, we estimated that 23892 eels (18 206 to 29578 ranging 275 from lowest to highest estimation) were caught in 2005. Given that the mean weight of 276 eels kept by fishermen was $127.7 \mathrm{~g}$ ( \pm 5.7 S.E.), the estimated total biomass of eels kept 277 was $3052 \mathrm{~kg}(2222 ; 3947)$.

278 Based on the spatial distribution of the fishing activity, we found that harvest by 279 fishermen (in eel·ha ${ }^{-1}$ ) varied largely between zones and gears (Figure 2). The highest 280 harvest by fishermen was found in the southern part of the GBM (zones 3 and 4) for all 281 gear types, and the northern part of the GBM (zones 1 and 2), which was mainly fished 282 with pots. The lowest harvest by fishermen occurred in the eastern part (zones 5, 6, 7 and 283 8; Figure 1 and Figure 2). Because fish spears accounted for a restricted part of the 284 catches (5\%), data related to this gear have been removed from the analysis of targeted 
285 eel size-classes per gear type. Based on creel surveys, fishermen using pots and square 286 dipping net caught eels from 240 to $760 \mathrm{~mm}$ total length and $33.5 \%$ of the total eel 287 captures $(n=257)$ were released by fishermen. The size distribution differed between 288 released and kept eels (Kolmogorov-Smirnov two-sample test, $\mathrm{KS}=0.678, \mathrm{P}<0.001$ ) 289 and released individuals were on average smaller than those kept (Mann-Whitney test, U $290=13.950, \mathrm{P}<0.001)$. Fishermen released on average $79.4 \%$ ( \pm 5.1 S.E.) of smaller eels 291 (from 240 to $320 \mathrm{~mm}$ ) and kept a high ratio (up to $60 \%$ ) of eels measuring more than $292320 \mathrm{~mm}$. From 420 to $620 \mathrm{~mm}$, all eels (100\%) were kept. Interestingly, some fishermen 293 tended to release some of the larger eels (Figure 3). Thus, based on their size, eels were 294 classified into those untargeted and targeted by the fishery using the $320 \mathrm{~mm}$ threshold.

\section{Eel population characteristics}

In 2004 and 2005, we captured 1868 eels: 681 by electrofishing, 921 by trapping

298 and 266 during the fishermen creel surveys (see Table 1 for details). There was no 299 difference in the size-class distribution between 2004 and 2005 for the eels sampled by 300 trapping and by electrofishing (Kolmogorov-Smirnov two-sample test, $\mathrm{P}>0.05$ ) or in the 301 mean abundance per site by electrofishing (Mann-Whitney test, P > 0.05). Eels up to 320 $302 \mathrm{~mm}$ sampled by trapping in fished areas were on average smaller than those from 303 protected areas (Mann-Whitney test, $\mathrm{U}=63.853, \mathrm{P}<0.001, \mathrm{n}=891$ ) and size-class 304 distribution differed significantly between protected and fished areas (Kolmogorov305 Smirnov two-sample test, $\mathrm{KS}=0.164, \mathrm{P}<0.001, \mathrm{n}=891$, Figure 4). Based on data 306 collected by trapping and using equation (1), we found different mean mortality rates Z 307 between protected and fished areas, $12 \% \cdot$ year $^{-1}$ and $32 \% \cdot y^{-1} r^{-1}$, respectively (Figure 4 ). 308 We also found that the differences in abundance between untargeted (TL < $320 \mathrm{~mm}$ ) and 
309 targeted (TL > $320 \mathrm{~mm}$ ) eels were positively correlated with the harvest by fishermen 310 from protected to highly fished zones (Linear regression, $\mathrm{R}^{2}=0.51, \mathrm{P}=0.021, \mathrm{n}=10$,

311 Figure 5). Based on data collected by trapping, we found that the proportion of silver eels

312 was higher in protected than in fished areas (Fisher's exact test, $\mathrm{P}=0.003$ ). Indeed,

$31312.83 \%$ of eels $>320 \mathrm{~mm}(\mathrm{n}=265)$ caught in protected areas presented silvering criteria

314 (i.e., ocular hypertrophy and differentiation of the lateral line) whereas only $2.86 \%$ ( $\mathrm{n}=$

315 102) presented these criteria in fished areas. Thus, the proportion of silver eels was 4.5

316 times higher in protected areas than in fished areas. The proportion of silver eels in eels

317 greater than $320 \mathrm{~mm}$ in length did not differ in fished area between data from

318 electrofishing $(4.65 \%, \mathrm{n}=86)$ and trapping (Fisher's exact test, $\mathrm{P}>0.5)$. The proportion

319 of silver eels was $1.42 \%$ (i.e., 4/282) when all size-classes from electrofishing were used

320 in the fished areas (Table 2). The proportion of silver eels in the protected areas reached

$3216.38 \%$. The sex-ratio of silver eels was largely biased towards females: 1/37 by trapping

322 and 0/5 by electrofishing, with no differences between fished and protected areas and 323 sampling methods (Fisher's exact test, $\mathrm{P}>0.05$, Table 2). Silver eels had an average 324 weight of $585.4 \mathrm{~g}( \pm 46.8$ S.E., $\mathrm{n}=29)$, a mean length of $675.8 \mathrm{~mm}( \pm 17.5$ S.E. $)$, and a 325 mean condition factor 0.18 ( \pm 0.01 S.E. $)$.

\section{Stock assessment, fishing mortality and silver eel production}

328 The mean estimated eel density was highly variable between zones (234.2 ind.ha ${ }^{-1}$ $329 \pm 42.4$ S.E.), ranging from 94.1 to 577 ind.ha $^{-1}$. The overall stock of eels $>150 \mathrm{~mm}$ was 330 estimated to be 129076 (74 022 to 200 206) individuals (see Table 3 for details). Based 331 on equation (3), the total mortality rates in protected and fished areas and the stock 332 assessment of eel under full exploitation, we estimated that total harvest by fishermen 
333 accounted for 10630 eels (5231 to 16994). Based on the proportion of silver eels 334 calculated in fished and protected areas, we estimated the silver eels production to be 3351961 (1431 to 2000) individuals.year ${ }^{-1}$, with a mean production of 11.3 and 3.1 silver

336 eel $\cdot h^{-1}$ in the protected and fished areas, respectively. Thus, the mean production of 337 silver eels in a protected area would be 3.6 times higher than in the fished area. The 338 production of the protected areas, that cover $2.4 \%$ of the total aquatic area (596.6 ha), 339 would represent $8.4 \%$ ( \pm 0.43 S.E.) of the silver eel biomass produced in the whole study 340 area. We estimated that a fully protected GBM would produce 6742 silver eels (596.6 $341 \mathrm{ha} \cdot 11.3 \mathrm{eel}^{-h^{-1}}{ }^{-1}$. The GBM is currently estimated to produce 1961 silver eels, thus the 342 fishery activity currently is estimated to remove approximately $71 \%$ of the silver eel 343 production of a fully protected GBM. Then, it is possible to estimate the surface of 344 marshes to be protected, in accordance with a management objective. For example, 50\% 345 of the potential eel biomass of a fully protected GBM would represent 3371 silver eels. 346 Considering that the protected area would always have a mean production of silver eels 347 3.6 times higher than those in the fished area (i.e., 11.3 and 3.1 silver eels $\cdot \mathrm{ha}^{-1}$, 348 respectively), 3371 silver eels could be produced with $31.1 \%$ of the GBM protected. 349 Indeed, 31.1\% of protected area (185.5 ha) would produce 2096 silver eels and 411.1 ha 350 of fished areas would produce 1275 silver eels. Consequently, only 31.1\% (185.5 ha) of 351 protected aquatic habitat of the GBM would produce, with the unprotected area, $50 \%$ of 352 the potential eel biomass of a fully protected Grande Brière Mottière.

\section{Discussion}


Freshwater protected areas: a compromise between eel global management and local

356 fishery activities

The analysis of catch data and scientific surveys in the GBM freshwater marshes between 2004 and 2005 provided evidence for the efficiency of a protection policy for guaranteeing a local production of silver eels and maintaining a traditional fishery activity. Indeed, the protected area showed a mean production of silver eel (ind $\cdot h a^{-1}$ ) around 3.6 times more than the fished areas and 2.4\% (14.6 ha) of protected area in the GBM produces $8.4 \%$ of the current silver eel production (in biomass). Consequently, a size adjustment of the protected areas to $31.1 \%$ (185.5 ha of aquatic habitat) with maintaining the current fishery in the remaining parts might produce $50 \%$ of the potential eel biomass of a fully protected Grande Brière Mottière. This could be a management target usable by local managers. Nevertheless, the optimal size of protected areas is difficult to estimate because the consequences of the protected areas extension have never been thoroughly investigated to establish valid rules for the design of freshwater protected areas (size, connectivity, location, land covered, etc.), or the creation of new habitats (ditches) in the existing protected area. Another crucial point is that we do not know the proportion of individuals that escape from the silver eel fishery when they migrate seaward and reach safely the spawning area as well as the level of eel movements between protected and fished areas within the marsh.

The conservation of freshwater fish and fisheries is the greatest challenge facing the sustainable development of inland waters (Arlinghaus et al. 2002). Inland fisheries are of high economic and socio-cultural importance, providing a 'myriad of benefits to society' (Arlinghaus et al. 2002; Cowx \& Gerdeaux 2004). By far the most dominant traditional inland fisheries management practises in Europe are regulations and stocking. 
379 To a lesser extent, inland fisheries management uses habitat restoration to increase the 380 potential production of the fishery (see review in Arlinghaus et al. 2002). The use of 381 freshwater protected areas to manage eel populations is in keeping with the last aspect. 382 Because the management of the wide panmictic European eel population is particularly 383 complex (such a challenge has never happened before), it faces some highly variable 384 socio-economic and legislation constraints. Therefore, case-adapted management options 385 with respect to usages, properties and histories, must be considered to significantly 386 increase silver eel production. The use of local freshwater protected areas appears to be a 387 relevant way to reconcile these aspects and to respond to both global management 388 constraints and local fisheries subsistence.

390 Contribution of small coastal marshes to the European eel population

391 Small coastal marshes contribute to the overall growth and reproduction of the 392 European eel population by precise quantification remains impossible. In the present 393 study, we estimated that a single marsh on the European Atlantic coast (GBM 7000 ha 394 total area) supports a sub-population of about 130000 eels and potentially produces 395 about 1961 silver eels per year, almost exclusively composed of females. Coastal marshes 396 cover 230000 ha of land on the western French coast (Feunteun et al. 1992). Given our 397 findings in the present study, it can be assumed that these ecosystems produce a 398 significant number of female silver eels. Moreover, eels produced in coastal marshes are 399 exposed to fewer hazards than those in rivers because such marshes are not equipped with 400 hydroelectric stations, that damage or kill 20 to $100 \%$ of the silver migrants passing 401 through their turbines (Travade \& Larinier 1992; McCleave 2001; Gibson \& Myers 2002). 402 In addition, these coastal marshes are small, only connected to the sea, and they are part 
403 of non-intensive agricultural landscapes. Together these factors probably account for the 404 quality of the silver eel production. It is especially interesting to consider that coastal 405 marshes characteristics can influence the sex ratio. In places where the eel abundance is 406 about 100-150 kg.ha ${ }^{-1}$ (110-170 kg.ha ${ }^{-1}$ on the Frémur River, Acou et al. in press; 90-159 407 kg.ha ${ }^{-1}$ on the Rio Esva, Lobon-Cervia et al. 1995), silver eels are mainly males (94.7\% 408 and $>99 \%$ for the Frémur River and the Rio Esva, respectively), whereas when the eel 409 abundance is relatively low (3.5 kg.ha ${ }^{-1}$ on the Imsa River, Vøllestad \& Jonsson 1988;

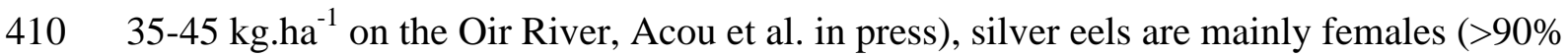
411 and around 80\% for the Imsa and Oir Rivers, respectively). Thus, the observed over412 dominance of females in the GBM and the low abundance of yellow eels (15.4 kg.ha ${ }^{-1}$, 413 see Table 3) are consistent with observations from other areas with low abundance where 414 females are the numerically dominant sex. On the other hand, the proportion of silver eels 415 observed in the GBM is comparable to those reported in other systems at the same 416 latitude (6.0 and 12.6\% in Oir and Fremur rivers, respectively, Acou et al. 2005; 8.7 and $4178.9 \%$ in the Fremur river, Feunteun et al 2000; 5.9, 1.3 and 5.8\% in the Fremur river in 418 2000, 2001 and 2002 respectively, Acou et al. in press). As Vøllestad (1990) 419 recommended retaining yellow-eel fishery activity in order to maximize the silver eel 420 fishery landings, it seems likely that, by limiting the yellow eel abundance in the GBM to 421 less than $50 \mathrm{~kg} \cdot \mathrm{ha}^{-1}$, the traditional fishery might contribute to the local production of 422 large silver eels. This might be influenced by a low recruitment that leads to a low elver 423 eel abundance, and by the high food availability due to the recent introduction of the 424 invasive red swamp crayfish (Procambarus clarkii) that can be preyed by eels (Domingos 425 et al. 2006). 
Such prospects are crucial from a conservation viewpoint since one of the main

427 recommendations of international managers (EELREP 2005; ICES WGEEL 2006) is to

428 protect aquatic systems with a high proportion of large healthy silver eels. In the present

429 study, we quantified fishing practices and evaluated their influence on the local eel

430 population. Such issues are important since the identification of mortality causes and

431 their quantification are difficult in the wild but are keys for international eel management

432 (Feunteun et al. 2000; Feunteun 2002). The presence of protected areas allowed us to

433 determine the mean natural mortality was relatively low in the marsh $\left(12 \% \cdot \mathrm{year}^{-1}\right)$ and

434 comparable to those observed in others ecosystems for the same life stages (Adam 1997;

435 Feunteun et al. 2000). Nevertheless, our estimation of fishermen's captures based on 436 biological data, i.e. 10630 individuals (5231 to 16994), was somewhat lower than that 437 resulting from questionnaires, i.e. 23882 individuals (18206 to 29578). This might arise 438 because fishermen had difficulties to evaluate their catches accurately, underlining the 439 importance of logbooks to conduct fishery surveys.

441 Establishment of freshwater protected area

$442 \quad$ Freshwater protected areas have already been shown to be efficient for conserving 443 bird and fish diversity (Eybert et al. 1998; Keith 2000; Self 2005) and their adaptation for 444 the local eel population management could be included in the overall management of 445 freshwater biodiversity (Noble et al. 2004). Recent research in marine protected areas has 446 demonstrated that fish populations benefit from protected areas not just for overexploited 447 poorly mobile species, but also (to a lesser extent) for under-exploited stocks and highly 448 mobile species (Apostolaki et al. 2002). Thus the creation of freshwater protected areas 
449 might also benefit vulnerable or endangered freshwater fish species, such as has already

450 been advocated for the Northern pike, Esox lucius (Rosell \& MacOscar 2002).

451 The efficiency of protected areas in other inland ecosystems remains to be

452 assessed. Concerning estuarine and coastal waters, Naismith \& Knights (1990) indicated

453 that the commercial fishery in the Thames estuary was having minimal impacts on the eel

454 stock, and fishing mortality was masked by natural mortality and migration effects. In the

455 same way, in the Hudson River estuary, Morrison \& Secor (2003) suggested that

456 brackish-water areas could support a higher fishing mortality than freshwater areas. Such

457 analysis confirms that protected areas for eels might not be relevantly usable in open

458 habitats like estuaries or coastal areas, and that this management tool might be

459 preferentially applied in confined freshwater areas such as coastal marshes (Morrison \&

460 Secor 2003). Furthermore, the restricted yellow eel home range in several types of

461 freshwater ecosystems (Baras et al. 1998; Jellyman \& Sykes 2003; Laffaille et al. 2005a)

462 offers opportunity for a wider application of this measure.

464 Acknowledgments

465 We thank the Parc naturel régional de Brière for logistic support, the Pnrb, FEDER, 466 DIREN (MEDD), Région Pays de la Loire and Agence de l'Eau from Loire-Bretagne for 467 financial support. We are grateful to the numerous persons that participated to field work 468 and to the questioned fishermen. We acknowledge three anonymous referees for valuable 469 comments on an earlier draft. English style was post-edited by Dr R. Britton. We thank A.

470 Acou and E. Rivot for valuable discussion on earlier draft.

\section{References}


474 Acou, A., Boury, P., Laffaille, P., Crivelli, A.J. \& Feunteun, E. 2005. Towards a 475 standardized characterization of the potentially migrating silver European eel 476 (Anguilla anguilla L.). Archiv für Hydrobiologie 164: 237-255.

477 Acou, A., Gabriel, G. \& Feunteun, E. (in press). Differential production and condition 478 indices of premigrant eels (Anguilla anguilla) in two small Atlantic coastal $479 \quad$ catchments of France. American Fisheries Society Symposium.

480 Adam, G. 1997. L’anguille européenne (Anguilla anguilla L. 1758): dynamique de la 481 sous-population du lac de Grand-Lieu en relation avec les facteurs environnementaux 482 et anthropiques. Thesis, University of Toulouse III, France, 353 pp.

483 Apostolaki, P., Milner-Gulland, E.J., McAllister, M.K. \& Kirkwood, G.P. 2002. 484 Modeling the effects of establishing a marine reserve for mobile fish species. 485 Canadian Journal of Fisheries and Aquatic Sciences 59: 405-415.

486 Arlinghaus, R., Mehner, T. \& Cowx, I.G. 2002. Reconciling traditional inland fisheries 487 management and sustainability in industrialized countries, with emphasis on Europe. $488 \quad$ Fish and Fisheries 3: 261-316.

489 Baras, E., Jeandrain, D., Serouge, B. \& Philippart, J.C. 1998. Seasonal variations in time 490 and space utilization by radio-tagged yellow eels Anguilla anguilla (L.) in a small $491 \quad$ stream. Hydrobiologia 371/372: 187-198.

492 Bernard, J.Y. \& Rolland, R. 1990. Restoration of the "Grande Brière Mottière" marsh overhauling's project of the stretches of water. Bulletin d'Ecologie 21: 15-19.

494 Broad, T.L., Townsend, C.R., Closs, G.P. \& Jellyman, D.J. 2001. Microhabitat use by 495 longfin eels in New Zealand streams with contrasting riparian vegetation. Journal of $496 \quad$ Fish Biology 59: 1385-1400. 
Copp, G.H. 1989. Electrofishing for fish larvae and juveniles: equipment modifications for increased efficiency with short fishes. Aquaculture and Fisheries Management 20:

Copp, G.H. \& Garner, P. 1995. Evaluating microhabitat use of fish larvae and juveniles with Point Abundance Sampling. Folia Zoologica 44: 145-158.

Cowx, I.G. \& Gerdeaux, D. 2004. The effects of fisheries management practises on freshwater ecosystems. Fisheries Management and Ecology 11: 145-151.

Dekker, W. 2003. Did lack of spawners cause the collapse of the European eel, Anguilla anguilla? Fisheries Management and Ecology 10: 365-376.

Domingos, I., Costa, J.L. \& Costa, M.J. 2006. Factors determining length distribution and abundance of the European eel, Anguilla anguilla, in the River Mondego (Portugal). Freshwater Biology 51: 2265-2281.

Durif, C., Dufour, S. \& Elie, P. 2005. The silvering process of Anguilla anguilla: a new

512 EELREP. 2005. Estimation of the reproduction capacity of European eel. Final report, EU contract Q5RS-2001-01836, 272p.

514 Eybert, M.-C., Bernard, J.-Y., Constant, P., Feunteun, E., Hédin, J. \& Questiau, S. 1998. 515 Réhabilitation des prairies inondables dans les marais briérons: évolution de la flore, 516 des poissons et des oiseaux. Gibier et Faune sauvage 15: 999-1016.

517 Feunteun, E., Rigaud, C., Elie, P. \& Lefeuvre, J.C. 1992. Les marais doux endigués de 518 Bourgneuf-Machecoul (Pays de Loire). Premiers éléments de connaissance du 519 peuplement piscicole. Relation ichtyofaune-habitat et problèmes majeurs de gestion. 520 Revue Française des Sciences de l’Eau 5: 509-528. 
521 Feunteun, E., Acou, A., Laffaille, P. \& Legault, A. 2000. European eel (Anguilla 522 anguilla): prediction of spawner escapement from continental population parameters. 523 Canadian Journal of Fisheries and Aquatic Sciences. 57: 1627-1635.

524 Feunteun, E. 2002. Management and restoration of European eel population (Anguilla 525 anguilla): an impossible bargain. Ecological Engineering 18: 575-591.

526 Gibson, A.J. \& R.A. Myers. 2002. A Logistic Regression Model for Estimating Turbine 527 Mortality at Hydroelectric Generating Stations. Transactions of the American $528 \quad$ Fisheries Society 131:623-633.

529 ICES WGEEL. 2006. Report of the ICES/EIFAC Working Group on Eels. 23-27 January $530 \quad$ 2006, Rome, Italy.

531 Jellyman, D.J. \& Sykes, J.R.E. 2003. Diel and seasonal movements of radio-tagged 532 freshwater eels Anguilla spp., in two New Zealand streams. Environmental Biology 533 of Fishes 66: 143-154.

534 Keith, P. 2000. The part played by protected areas in conservation of threatened French 535 freshwater fish. Biological Conservation 92: 265-273.

536 Knights, B. \& White, E. 1998. Enhancing immigration and recruitment of eels: the use of 537 passes and associated trapping systems. Fisheries Management and Ecology. 5: 459$538 \quad 471$

539 Knights, B., White, E. \& Naismith, I.A. 1996. Stock assessment of European eel, 540 Anguilla anguilla L. In Cowx, I.G. (ed) Stock Assessment in Inland Fisheries. $541 \quad$ Fishing News Books, Oxford p 431-447.

542 Laffaille, P., Briand, C., Fatin, D., Lafage, D. \& Lasne, E. 2005a. Point sampling the 543 abundance of European eel (Anguilla anguilla) in freshwater areas. Archiv für $544 \quad$ Hydrobiologie 162: 91-98. 
545 Laffaille, P., Acou, A. \& Guillouët, J. 2005b. The yellow European eel (Anguilla anguilla

546 L.) may adopt a sedentary lifestyle in inland freshwaters. Ecology of Freshwater Fish $547 \quad$ 14: 191-196.

548 Leslie, H. 2005. A synthesis of marine conservation planning approaches. Conservation $549 \quad$ Biology 19: 1701-1713.

550 Lobon-Cervia, J. \& Utrilla, C. 1993. A simple method to determine stream trout (Salmo 551 trutta L.) densities based on one removal fish electrofishing. Fisheries Research 15: $552 \quad 369-373$.

553 Lobon-Cervìa, J., Utrilla C.G. \& P.A. Rincon. 1995. Variations in the population 554 dynamics of the European eel Anguilla anguilla (L.) along the course of a Cantabrian $555 \quad$ river. Ecology of Freswater Fish 4:17-27.

556 Lundquist, C.J. \& Granek, E.F. 2005. Strategies for successful marine conservation: 557 integrating socioeconomic, political and scientific factors. Conservation Biology 19: $558 \quad$ 1771-1778.

559 McCleave, J.D. 2001. Simulation of the impact of dams and fishing weirs on 560 reproductive potential of silver-phase American eels in the Kennebec River Basin, 561 Maine. North American Journal of Fisheries Management 21:592-605.

562 Maitland, P.S. 1995. The conservation of freshwater fish: past and present experience. $563 \quad$ Biological Conservation 72: 259-270.

564 Moriarty, C. \& Dekker, W. 1997. Management of European eel fisheries. Second report 565 of EC concerted action AIR A94-1939. Dublin, Ireland: Fisheries Bulletin Marine $566 \quad$ Institute, Vol. 15, 110 pp. 
Morrison, W.E. \& Secor, D.H. 2003. Demographic attributes of yellow-phase American eels (Anguilla rostrata) in the Hudson River estuary. Canadian Journal of Fisheries and Aquatic Sciences 60: 1487-1501.

570 Naismith, I.A. \& Knights, B. 1990. Modelling of unexploited and exploited populations

571 of eels, Anguilla anguilla (L.), in the Thames estuary. Journal of Fish Biology 37: $572 \quad 975-986$.

573 Naismith, I.A. \& Knights, B. 1990. Studies of sampling methods and of techniques for 574 estimating populations of eels, Anguilla anguilla L. Aquaculture and Fisheries $575 \quad$ Management 21: 357-367.

576 Nelva, A., Persat, H. \& Chessel, D. 1979. Une nouvelle méthode d'étude des 577 peuplements ichthyologiques dans les grands cours d'eau par échantillonnage 578 ponctuel d'abondance. Comptes Rendus de l'Académie des Sciences 289: 1295$579 \quad 1298$.

580 Noble, R.A.A., Harvey, J.P. \& Cowx, I.G. 2004. Can management of freshwater fish 581 populations be used to protect and enhance the conservation status of a rare, fish582 eating bird, the bittern, Botaurus stellaris, in the UK? Fisheries Management and $583 \quad$ Ecology 11: 291-302.

584 Robinet, T. \& Feunteun, E. 2002. Sublethal effects of exposure to chemical compounds: a $585 \quad$ cause for the decline in Atlantic eels ? Ecotoxicology 11:265-277.

586 Rosell, R.S., \& MacOscar, K.C. 2002. Movements of pike, Esox lucius, in Lower Lough 587 Erne, determined by mark-recapture between 1994 and 2000. Fisheries Management $588 \quad$ and Ecology 9: 189-196. 
Rosell, R., Evans, D. \& Allen, M. 2005. The eel fishery in Lough Neagh, Northern Ireland - an example of sustainable management? Fisheries Management and Ecology. 12: 377-385.

Roth, E., Toivonen, A.L., Navrud, S., Bengtsson, B., Godbergsson, G., Tuunainen, P., Appelblad, H. \& Weissglas, G. 2001. Methodological, conceptual and sampling practices in surveying recreational fisheries in Nordic countries - experiences from a valuation survey. Fisheries Management and Ecology 8: 355-367.

596 Saunders, D.L., Meeuwig, J.J. \& Vincent, A.C.J. 2002. Freshwater protected areas: 597 strategies for conservation. Conservation Biology 16: 30-41.

598 Self, M. 2005. A review of management for fish and bitterns, Botaurus stellaris, in $599 \quad$ wetland reserves. Fisheries Management and Ecology 12: 387-394.

600 Schulze, T., U. Kahl, R.J. Radke, \& J. Benndorf. 2004. Consumption, abundance and 601 habitat use of Anguilla anguilla in a mesotrophic reservoir. Journal of Fish Biology

603 Sparre, P. \& Venema, S.C. 1998. Introduction to tropical fish stock assessment. Part 1. 604 Manual. FAO Fisheries Technical Paper. No. 306.1, Rev. 2., FAO, Rome. 407 pp. 605 Starkie, A. 2003. Management issues relating to the European eel, Anguilla anguilla. $606 \quad$ Fisheries Management and Ecology 10: 361-364.

607 Stem, C., Margoluis, R., Salafsky, N. \& Brown, M. 2005. Monitoring and evaluation in 608 conservation: a review of trends approaches. Conservation Biology 19: 295-309.

609 Tesch, F.W. 2003. The eel. Fifth edition. Blackwell, Oxford.

610 Travade, F. \& Larinier, M. 1992. La migration de dévalaison: problèmes et dispositifs. 611 Bulletin Français de la Pêche et de la Pisciculture 326:165-176. 
612 Vøllestad, L.A. \& B. Johnson. 1988. A 13-year study of the population dynamics and 613 growth of the European eel Anguilla anguilla in a Norwegian river: evidence for 614 density-dependent mortality, and development of a model for predicting yield. 615 Journal of Animal Ecology 57:983-997.

616 Vøllestad, L.A. 1990. Optimal management of European eel in the Imsa River, Norway. 617 Journal du Conseil international d’Exploration de la Mer 46:115-120.

618

619 
622

623

624

626

627

629

630

631

632

Table 1: Sampling design of the eel population and traditional fishery surveys in protected and fished areas of the Grande Brière Mottière marsh in 2004 and 2005.

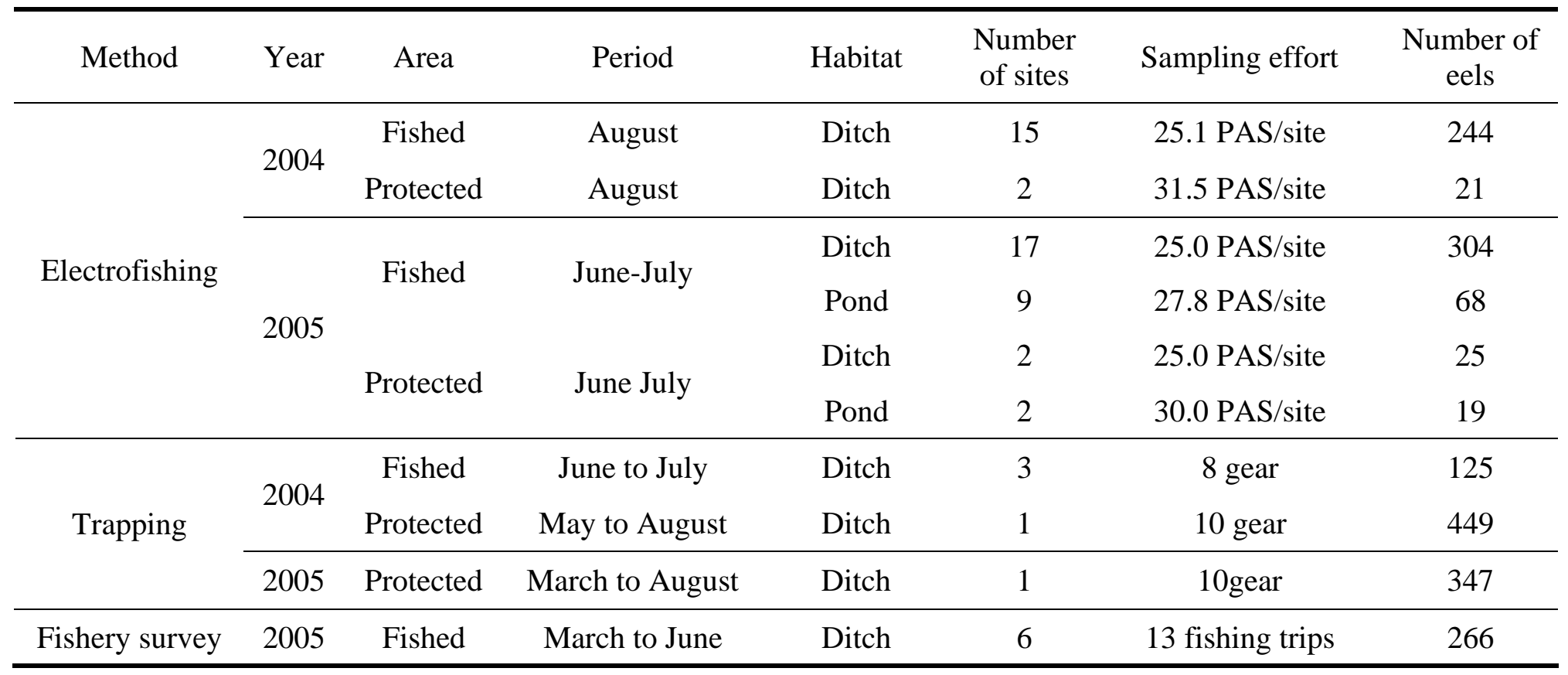


634 Table 2: Number of eels and silver eels (males and females) caught by electrofishing and 635 trapping in 2005 in the protected and fished areas of Grande Brière Mottière marsh. See 636 details on sampling procedure and effort in the text.

637

\begin{tabular}{llccc}
\hline Sampling method & Parameters & Fished area & Protected area & Total \\
\hline \multirow{4}{*}{ Electrofishing } & Total number & 282 & 24 & 306 \\
& Silver eels & 4 & 1 & 5 \\
& Males & 0 & 0 & 0 \\
& Females & 4 & 1 & 5 \\
\hline \multirow{4}{*}{ Trapping } & Total number & 105 & 265 & 370 \\
& Silver eels & 3 & 34 & 37 \\
& Males & 0 & 1 & 1 \\
& Females & 3 & 33 & 36 \\
\hline
\end{tabular}

638

639 


\begin{tabular}{|c|c|c|c|c|c|c|c|c|}
\hline \multirow[b]{2}{*}{ Zone } & \multirow[b]{2}{*}{ Status } & \multirow[b]{2}{*}{$\begin{array}{c}\text { Aquatic } \\
\text { habitat (ha) }\end{array}$} & \multicolumn{3}{|c|}{ Eel population } & \multicolumn{3}{|c|}{ Silver eel production } \\
\hline & & & $\begin{array}{l}\text { Number of } \\
\text { Individuals }\end{array}$ & $\begin{array}{l}\text { Density } \\
\left(\text { ind }^{\prime} \mathrm{ha}^{-1}\right)\end{array}$ & $\begin{array}{l}\text { Biomass } \\
\left(\mathrm{kg} \cdot \mathrm{ha}^{-1}\right)\end{array}$ & $\begin{array}{l}\text { Number of } \\
\text { individuals }\end{array}$ & $\begin{array}{l}\text { Density } \\
\left(\text { ind }^{\prime} \mathrm{ha}^{-1}\right)\end{array}$ & $\begin{array}{l}\text { Biomass } \\
\left(\mathrm{kg} \cdot \mathrm{ha}^{-1}\right)\end{array}$ \\
\hline 1 & Fished & 69.7 & $\begin{array}{c}11450 \\
(6201 ; 20205)\end{array}$ & $\begin{array}{c}164.2 \\
(88.9 ; 289.7)\end{array}$ & $\begin{array}{c}11.84 \\
(5.58 ; 23.58)\end{array}$ & $\begin{array}{c}163 \\
(88 ; 287)\end{array}$ & $\begin{array}{c}2.3 \\
(1.3 ; 4.1)\end{array}$ & $\begin{array}{c}1.34 \\
(0.75 ; 2.39)\end{array}$ \\
\hline 2 & Fished & 160.7 & $\begin{array}{c}30875 \\
(18266 ; 35271)\end{array}$ & $\begin{array}{c}192.1 \\
(113.7 ; 219.5)\end{array}$ & $\begin{array}{c}8.67 \\
(4.86 ; 10.45)\end{array}$ & $\begin{array}{c}438 \\
(259 ; 501)\end{array}$ & $\begin{array}{c}2.7 \\
(1.6 ; 3.1)\end{array}$ & $\begin{array}{c}1.57 \\
(0.93 ; 1.81)\end{array}$ \\
\hline 3 & Fished & 12.9 & $\begin{array}{c}2610 \\
(1205 ; 6125)\end{array}$ & $\begin{array}{c}202 \\
(93.3 ; 474.1)\end{array}$ & $\begin{array}{c}10.05 \\
(4.21 ; 25.75)\end{array}$ & $\begin{array}{c}37 \\
(17 ; 87)\end{array}$ & $\begin{array}{c}2.9 \\
(1.3 ; 6.7)\end{array}$ & $\begin{array}{c}1.69 \\
(0.75 ; 3.91)\end{array}$ \\
\hline 4 & Fished & 25.7 & $\begin{array}{c}14832 \\
(8825 ; 30113)\end{array}$ & $\begin{array}{c}577 \\
(343.3 ; 1171.6)\end{array}$ & $\begin{array}{c}37.62 \\
(20.44 ; 83)\end{array}$ & $\begin{array}{c}211 \\
(125 ; 428)\end{array}$ & $\begin{array}{c}8.2 \\
(4.9 ; 16.7)\end{array}$ & $\begin{array}{c}4.79 \\
(2.86 ; 9.75)\end{array}$ \\
\hline 5 & Fished & 112.0 & $\begin{array}{c}24230 \\
(15317 ; 36474)\end{array}$ & $\begin{array}{c}216.3 \\
(136.7 ; 325.6)\end{array}$ & $\begin{array}{c}10.42 \\
(5.96 ; 17.17)\end{array}$ & $\begin{array}{c}344 \\
(218 ; 518)\end{array}$ & $\begin{array}{c}3.1 \\
(1.9 ; 4.6)\end{array}$ & $\begin{array}{c}1.81 \\
(1.11 ; 2.68)\end{array}$ \\
\hline 6 & Fished & 78.3 & $\begin{array}{c}23076 \\
(12816 ; 40970)\end{array}$ & $\begin{array}{c}294.7 \\
(163.7 ; 523.2)\end{array}$ & $\begin{array}{c}24.07 \\
(12.34 ; 46)\end{array}$ & $\begin{array}{c}328 \\
(182 ; 582)\end{array}$ & $\begin{array}{c}4.2 \\
(2.3 ; 7.4)\end{array}$ & $\begin{array}{c}2.45 \\
(1.34 ; 4.32)\end{array}$ \\
\hline 7 & Fished & 39.8 & $\begin{array}{c}9527 \\
(5282 ; 14489)\end{array}$ & $\begin{array}{c}239.5 \\
(132.8 ; 364.2)\end{array}$ & $\begin{array}{c}13.6 \\
(7.13 ; 21.81)\end{array}$ & $\begin{array}{c}135 \\
(75 ; 206)\end{array}$ & $\begin{array}{c}3.4 \\
(1.9 ; 5.2)\end{array}$ & $\begin{array}{c}1.98 \\
(1.11 ; 3.03)\end{array}$ \\
\hline 8 & Fished & 82.9 & $\begin{array}{c}9894 \\
(4574 ; 13112)\end{array}$ & $\begin{array}{c}119.4 \\
(55.2 ; 158.2)\end{array}$ & $\begin{array}{c}8.43 \\
(3.29 ; 12.89)\end{array}$ & $\begin{array}{c}140 \\
(65 ; 186)\end{array}$ & $\begin{array}{c}1.7 \\
(0.8 ; 2.2)\end{array}$ & $\begin{array}{c}0.99 \\
(0.46 ; 1.28)\end{array}$ \\
\hline 9 & Protected & 6.5 & $\begin{array}{c}614 \\
(419 ; 703)\end{array}$ & $\begin{array}{c}94.1 \\
(64.2 ; 107.8)\end{array}$ & $\begin{array}{c}5.85 \\
(3.49 ; 7.55)\end{array}$ & $\begin{array}{c}39 \\
(27 ; 45)\end{array}$ & $\begin{array}{c}6 \\
(4.1 ; 6.9)\end{array}$ & $\begin{array}{c}3.50 \\
(2.39 ; 4.03)\end{array}$ \\
\hline 10 & Protected & 8.1 & $\begin{array}{c}1968 \\
(1117 ; 2744) \\
\end{array}$ & $\begin{array}{c}242.8 \\
(137.8 ; 338.5)\end{array}$ & $\begin{array}{c}23.24 \\
(10.94 ; 37.91)\end{array}$ & $\begin{array}{c}126 \\
(71 ; 175) \\
\end{array}$ & $\begin{array}{c}15.5 \\
(8.8 ; 21.6)\end{array}$ & $\begin{array}{c}9.05 \\
(5.14 ; 12.6)\end{array}$ \\
\hline
\end{tabular}




\section{$644 \quad$ Figures captions}

645

646 Figure 1: Map of the Brière illustrating the ditch network, ponds, fished and protected

647 areas with their codes and the location of eel population survey. Different symbols

648 represent the location of the fishery surveys: ( $\mathbf{A})$ the trapping ( $\boldsymbol{\square})$ and the electrofishing

649 (•) during 2004 and 2005.

650

651 Figure 2: Geographical distribution of the harvest by fishermen (eel·ha ${ }^{-1}$ ) in each zone of

652 the fished area and for each eel fishing gear (eel pots, square dipping nets and fishing 653 spears).

654

655 Figure 3: Size-classes distribution of eels caught by fishermen during the creel survey 656 using eels pots $(n=184)$ and square dipping nets $(n=82)$ and percentage of eels kept by 657 fishermen for each size-class (white dots).

658

659 Figure 4: Size-classes distribution of $>320 \mathrm{~mm}$ eels trapped in fished $(\mathrm{n}=251)$ and 660 protected $(n=640)$ areas in 2004 and 2005.

661

662 Figure 5: Relationship between harvest by fishermen (eel·ha ${ }^{-1}$ ) in each zone of the study 663 area and the differences in abundance between untargeted (TL $<320 \mathrm{~mm}$ ) and targeted 664 (TL > 320 mm) eels.

665

666

667 

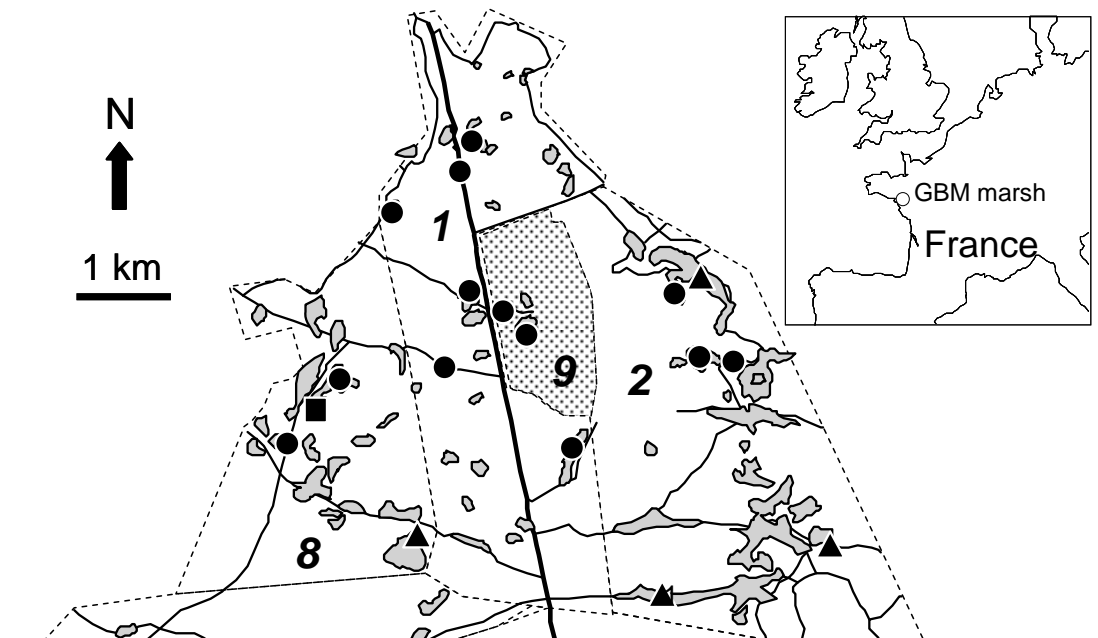

0 辽
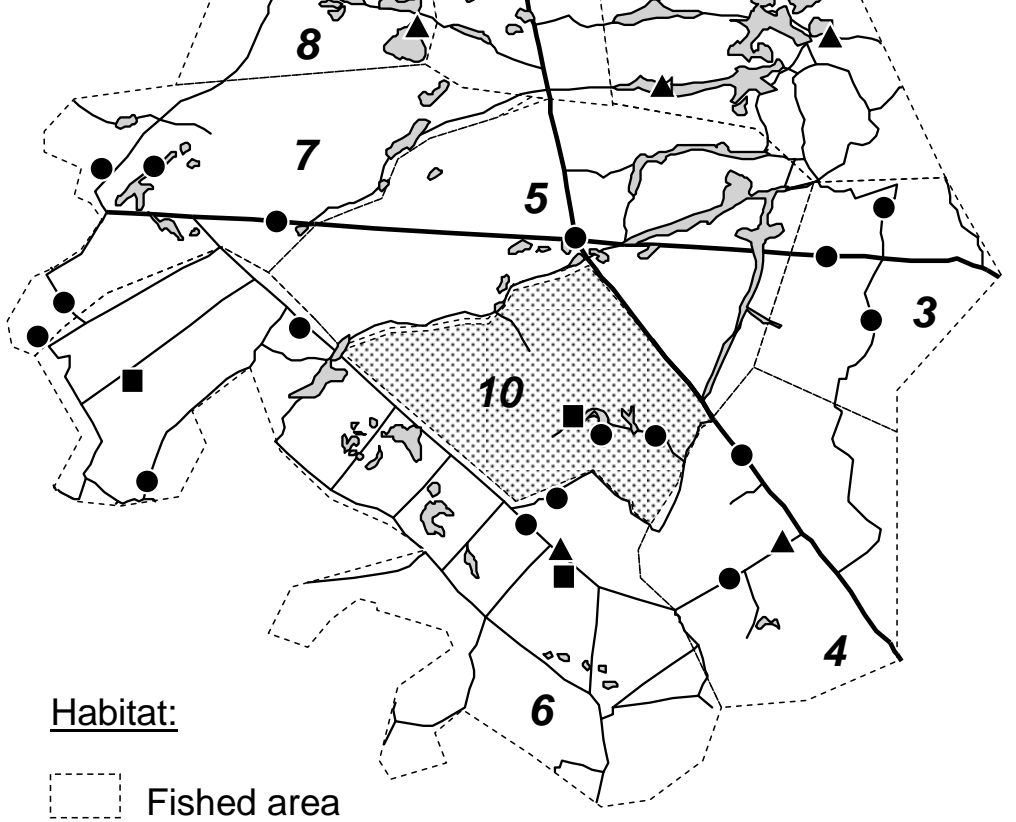

Fished area

Protected area

Eel population survey:

Water pond

- Fishery survey

- Trapping

Electrofishing

686

Figure 1

688

689

690

691 


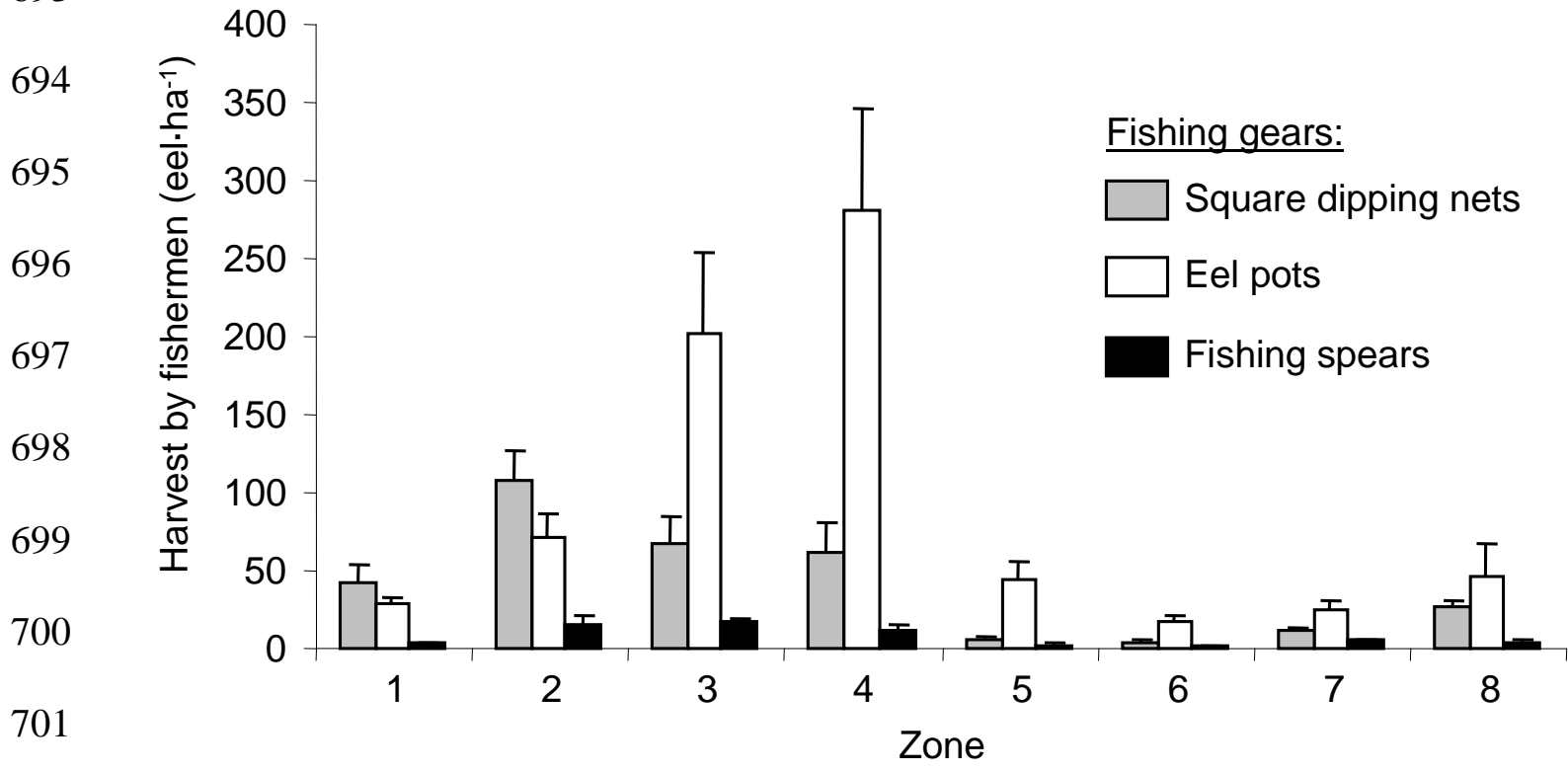

$702 \quad$ Figure 2

703

704

705

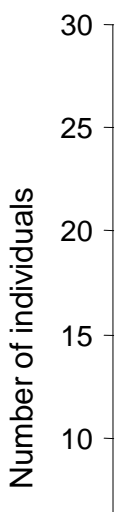

5

711

712

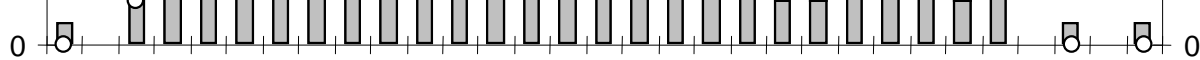

$\begin{array}{llllllllllllllll}200 & 240 & 280 & 320 & 360 & 400 & 440 & 480 & 520 & 560 & 600 & 640 & 680 & 720 & 760 & 800\end{array}$

713

Total length $(\mathrm{mm})$

$714 \quad$ Figure 3.

715 
60

718

719

720

721

722

723

724

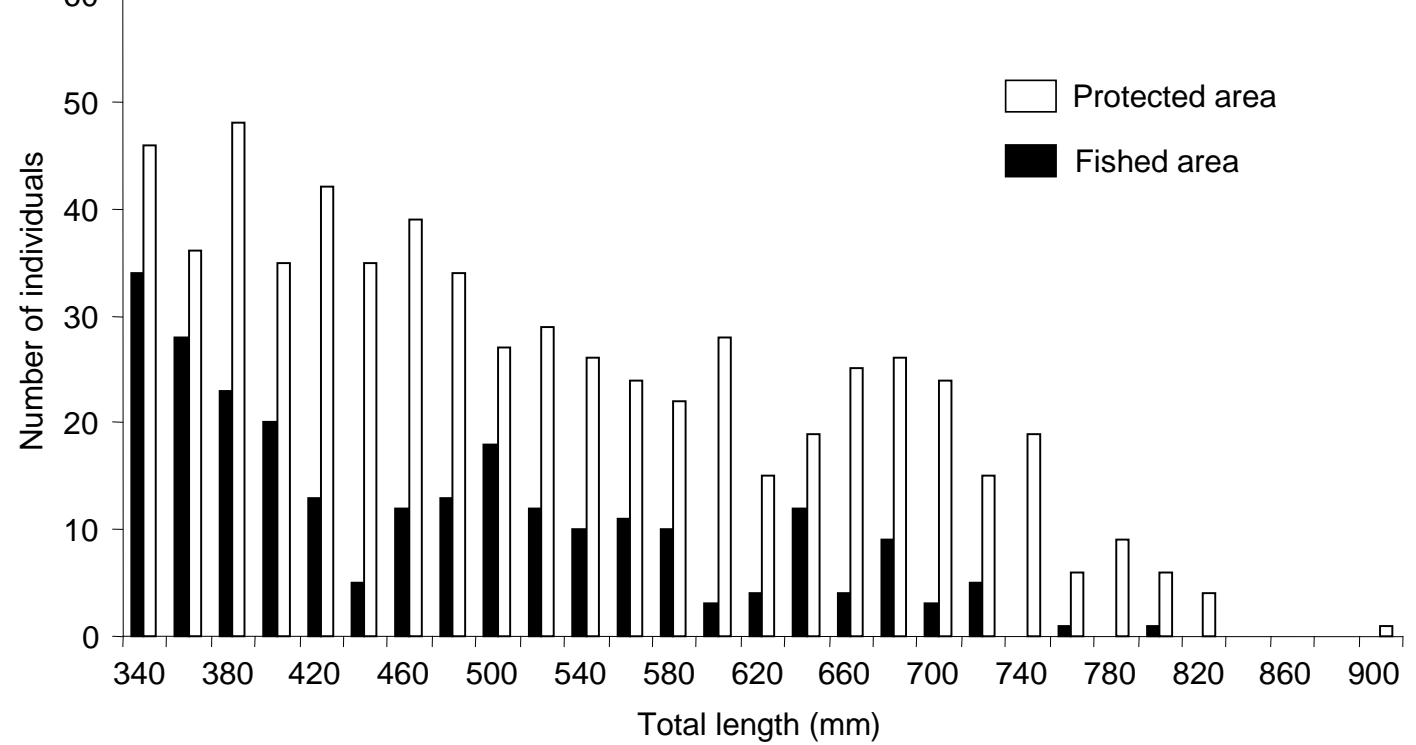

725

$726 \quad$ Figure 4

727

728

729

730

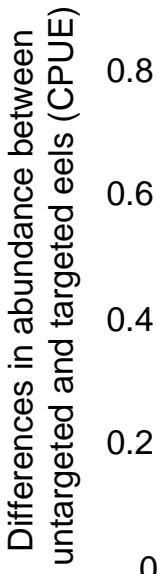

- Fished area

- Protected area

731

732

733

734

735

736

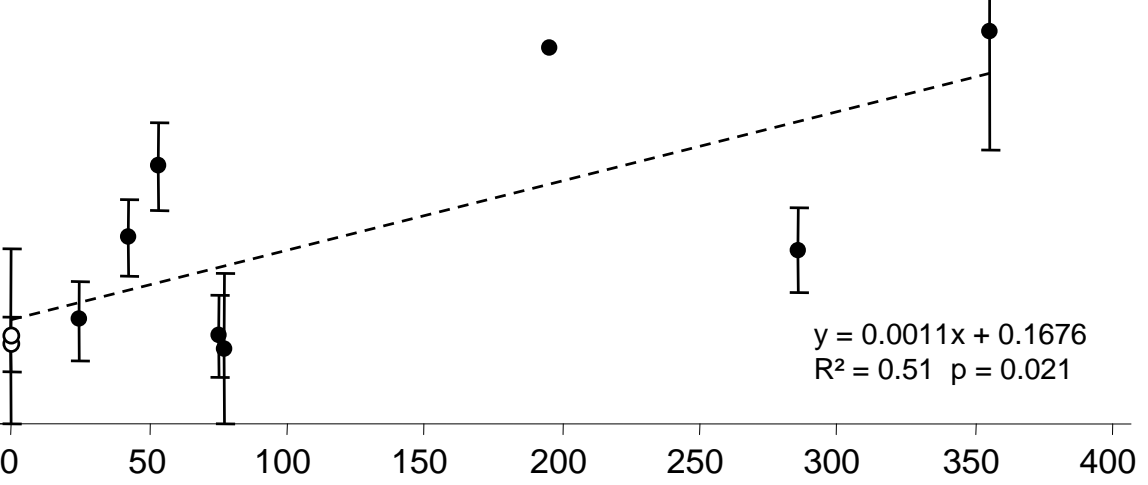

Harvest by fishermen (eel.ha-1)

737

$738 \quad$ Figure 5 